Journal of Advanced College of Engineering and Management, Vol. 5, 2019

\title{
PARTICIPATORY ACTION RESEARCH FOR LEARNING CHEMISTRY: A CASE OF PUBLIC SCHOOLS IN NEPAL
}

\author{
Kamal Prasad Acharya \\ Lecturer, Department of Science and Environment Education \\ Central Department of Education \\ Tribhuvan University \\ Kirtipur, Kathmandu
}

\begin{abstract}
The present study reconnoiters the application of participatory action research (PAR) in improving the performance of students in chemistry sections. A mixed method research is employed focusing PAR as qualitative and experimental as a quantitative with equivalent groups. Two schools were purposively selected (one leader and one leader) in Chitwan and Nawalparasi districts. All the students in the leader school are given intervention. Thirty students from the feeder school are in control group. Intervention was done by laboratory activities in chemistry teaching. PAR approach is used in the leader school during intervention. Pre-test and post-test were used to collect the data. Data are analyzed using inferential statistics: independent student t-test and analysis of covariance (ANCOVA). The result shows that the experimental group outperformed to control group suggesting that PAR approach enhanced performance of lower and high achievers more than the lecture method of teaching.
\end{abstract}

Keywords: Participatory action research, chemistry teaching, intervention

\section{Introduction}

PAR basically based on action research in the concern of planning, acting and reflecting mode to complete a cycle. The PAR approach turns the teacher as the research participants or co-researcher who involve in the activities (intervene). Inquiry-based learning is basically relates its base on critical pedagogy. PAR is the transformation of the teacher as the co-researcher that presents a power-sharing challenge to oppressive relationships premised on submission and dependence between the science teachers and the students. It also helps to advocate local voices, local realities and local wisdom in the course of completing all the cycles.PAR, according to Soloway, Kishbaugh, and Hayes (1999), "democratic practical knowing in the pursuit of worthwhile human purposes, grounded in a participatory worldview". PAR completes in cycles relating of theory, practice, and problem solving. Freire (1970, revised 1993), eminent for advancing critical consciousness (conscientization) and social action (praxis), shared the collective power gained by oppressed. Feasey (2012) is recognized for describing PAR as an integrated activity that combines social investigation, educational work and action (p. 7), designed to support those with less power in their organization. Ucar (2011) noted, "rhetoric of community involvement with risk of co-option and compared this to authentic participation, where communities control the research process".

PAR emphasizes both the authentic participation and relevancy of actions. It is practically refers by the terms such as community cooperative inquiry, emancipatory work, appreciative open inquiry, and community-based participatory research. According to Lisa, Martin, and Adams (2015), PAR learning has emerged as a new approach to classroom teaching in recent years. The approach is now accepted and preferred instructional procedure at all the levels of education in most of the western countries. Acharya (2016) argues, it is group learning activity organized in such a way that learning is dependent on the socially structured exchange of information between learners in group (p. 4).It is a research cum teaching strategy in which students, teachers and sometimes parents work cooperatively to cocreate the leaning in the classrooms. According to Klahr, and Nigam, (2004), it aims to transfer the 
classroom pedagogy from teacher centered pedagogy to activity based instruction (ABI). It ultimately aims todisseminate co-created knowledge into the society for the societal transformation. It is a theoretically validated teaching strategy in which small teams, each with students of different levels of ability, use a variety of learning activities to improve their understanding of a subject.

In Nepalese context, it is commonly observed that the classes are overdriven by "teacher talk" and teaching-learning process is predominantly text-book and examination oriented. Here, teacher serves as pipelines for source of knowledge and seek to transfer their knowledge and idea to passive students. They emphasize learning about answers more than an exploration of questions; "promote rote memory at the cost of critical thinking process" (Acharya, 2016), learning of segments of knowledge alternate to understanding in context (Shrestha, 2009), reading in lieu of doing (Hofstein, Kipnis \& Kind, 2008). This type of instructional method does not allow for active participation and interaction of students in the teaching-learning process. This creates monotony in the classroom and students' lost their interest in the subject. The classrooms are generally overcrowded and single teacher has to deal with large number of students. Here teacher found very less opportunity to give individual attention to all students.

Inquiry-based learning basically relates its base to critical pedagogy (Lazonder, \& Harmsen, 2016). Freire (1993) remarks, "emerge the confluence revolutionary pedagogy through the publication pedagogy of the oppressed" (p.47). PAR has certain key commitments and values in its endavour which Graesser and Olde (2003) describe as "beginning with the ontological possibility of a real popular science" (p. 151). It helps to advocate local voices, local realities and local wisdom in the course of completing all the cycles. These key characteristics of PAR are in line with McNeill (2003) and Ucar (2011), argue "connection of participatory research movement with emancipatory social change at broader levels, and thereby, with goals to which all social research should aspire".

\section{Methodology}

Qualitative aspect of the research applied PAR approach in which the basic level science teachers (coresearchers) help for the intervention activities in the classrooms along with the researcher. But to analyze the quantitative part, an experimental design was used. Sampled school was chosen purposefully according to the need and convenience of the researcher. Researcher employed intervention as well as pre-test post-test equivalent groups to find out impact of PAR on chemistry achievement and performance of basic level public school students.

\section{Population and Sample of the Study}

The population of the study is the total number of students studying at six grade at Jana Jiwan Higher Secondary School, Chitwan and Naba Durga Lower Secondary School, Nawalparasi. The sample of the study comprises 80students from both the leader and the feeder schools. Intervention was done among the students of leader schoolby teacher training programme, activity based instruction and learning from the garden whereas students from the feeder schools were controlled by traditional lecture method of teaching chemistry portions. Students were categories into higher and lower achievers on the basis of their two successive test scores in chemistryportion in previous standard.

\section{Tools of Data Collection}

To fulfil the objectives of the study, the following instruments were constructed and applied to collect data:

Chemistry Achievement Test (CAT) was developed by the researcher consisting of 50 itemsbased on the chemistry portion of grade six science curriculum i.e., elements and compounds, mixture and metals and non-metals. It was piloted and validated by calculating difficulty level and discrimination 
index of each item. The reliability coefficient of test was calculated by using the Kuder-Richardson formula and Cronbach coefficient (split half method of reliability) method, the values were found 0.67 and 0.838 respectively.

\section{Intervention and experimentation}

After the pre-test, the experimental group was subjected for orientation for PAR approach for 3 months. Then treatment was given the interventions like science teachers professional development, ABI, practical activities and garden pedagogy. Parallel to treatment of experimental group, the control group was taught by lecturemethod in the feeder school covering the same units of chemistry as in the experimental group. The lesson plans for the control group focused on same instructional objectives. After the intervention of 45 instructional periods (90 days), same CAT was administered to the students in both the leader and feeder schools.

\section{Result and Discussion}

Data were analyzed using SPSS statisticssoftware for the t-test followed by one-way analysis of covariance (ANCOVA). All values were expressed as mean $( \pm \mathrm{SE})$. P-value $<0.05$ was considered significant in the present study.

\section{Pre-test and Post-test Intervention Result (t-test) of Low Achievers}

Pre-test analysis of the low achiever students in both experimental and control group before and after intervention show no significant difference in chemistry achievement. It indicates that the CAT score at pre-level was not matched in both the group in terms of total score. After the intervention on PAR approach, both the group of students done better. It shows that CAT score in both the group was increased but when compared with the control group the values were found to be significantly high. It suggests the positive effect of PAR approaches in classroom pedagogy. The CAT score was significantly increased in separation of mixture $(31 \%, \mathrm{p}<0.000)$, metals and non-metals $(48.21 \%$, $\mathrm{p}<0.000)$, elements and compounds $(45.18 \%, \mathrm{p}<0.000)$ and total score $(39.91 \%, \mathrm{p}<0.000$ as compared to control group.

Table 1: Statistical Analysis of pre-test and post-test of Low Achievers

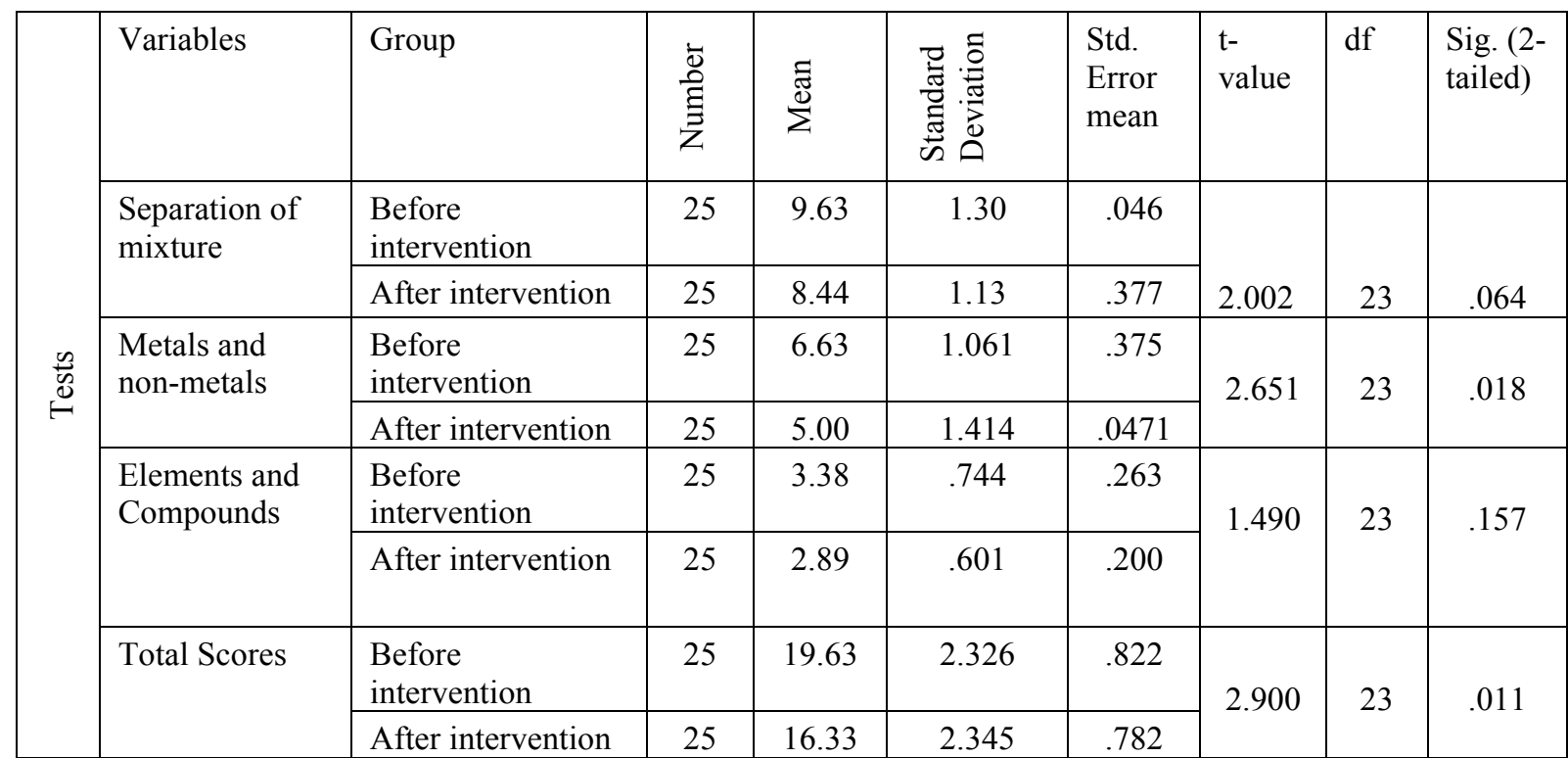


Table 2: ANCOVA Scores for Low Achiever Students

\begin{tabular}{|l|c|c|c|l|c|}
\hline \multicolumn{1}{|c|}{ Source } & Type III Sum of Squares & df & Mean Square & F & Sig. (2-tailed) \\
\hline Corrected Model & 1439.23 & 2 & 719.617 & 56.320 & .000 \\
\hline Intercept & 111.008 & 1 & 111.008 & 8.688 & .011 \\
\hline Pre_Total & 225.214 & 1 & 225.214 & 17.626 & .001 \\
\hline Group & 357.146 & 1 & 357.146 & 27.951 & .000 \\
\hline Error & 78.883 & 14 & 12.777 & & \\
\hline Total & 44821.000 & 17 & & & \\
\hline Corrected Total & 1618.118 & 16 & & & \\
\hline
\end{tabular}

$\mathrm{R}$ Squared $=.889($ Adjusted R Squared $=.874)$

Table 3: Estimated Marginal Means of Low Achievers

\begin{tabular}{|c|c|c|c|c|}
\hline \multirow{2}{*}{ Group } & \multirow{2}{*}{ Mean } & \multirow{2}{*}{ Std. Error } & \multicolumn{2}{|c|}{$95 \%$ Confidence Interval } \\
\cline { 3 - 5 } & & & Lower Bound & Upper Bound \\
\hline Before Intervention & 56.485 & 1.439 & 53.398 & 59.571 \\
\hline After Intervention & 45.014 & 1.339 & 42.141 & 47.886 \\
\hline
\end{tabular}

Covariates: Pre total Score Test 17.88

The ANCOVA analysis of lower achievers indicate that F-ratio at df 16 is $\mathrm{F}_{(1,16)}=29.951$ and $\mathrm{p}=0.000$ is significant at .0001 level. It verify our previous findings that PAR approach significantly enhances the chemistry achievement in low achievers. Estimated marginal means of the experimental group (56.48) is higher than control group (45.04)shown in Table 3.

\section{Pre-test and Post-test Intervention Result (t-test) of High Achievers}

Pre-test analysis of the high achievers in both groups before and after the intervention shows no significant difference in any of the variable and also in total CAT score. It clearly shows that the CAT score at pre-level was matched in both the group as the values were not significant.

The post-test analysis of high achievers show a significant increase in separation of mixture $(8.8 \%$, $\mathrm{p}<0.05)$, metals and non-metals $(29.44 \%, \mathrm{p}<0.001)$, elements and compounds $(27.86 \%, \mathrm{p}<0.01)$ and total score $(20.12 \%, \mathrm{p}<0.01)$ as compared to control group. 
Table 4: Statistical Analysis of pre-test and post-test of High Achievers

\begin{tabular}{|c|c|c|c|c|c|c|c|c|c|}
\hline \multirow{9}{*}{ 品 } & Variables & Group & $\begin{array}{l}\overline{\mathbf{D}} \\
\text { है } \\
\text { Z }\end{array}$ & $\sum_{\bar{\Xi}}^{\tilde{\Xi}}$ & 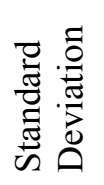 & $\begin{array}{l}\text { Std. } \\
\text { Error } \\
\text { mean }\end{array}$ & $\frac{\mathscr{O}}{\stackrel{0}{\pi}}$ & $\mathrm{df}$ & $\begin{array}{l}\text { Sig. (2- } \\
\text { tailed) }\end{array}$ \\
\hline & \multirow[t]{2}{*}{$\begin{array}{l}\text { Separation of } \\
\text { mixture }\end{array}$} & $\begin{array}{l}\text { Before } \\
\text { intervention }\end{array}$ & 15 & 30.88 & 1.642 & .0581 & \multirow[t]{2}{*}{2.224} & \multirow[t]{2}{*}{14} & \multirow[t]{2}{*}{.043} \\
\hline & & $\begin{array}{l}\text { After } \\
\text { intervention }\end{array}$ & 15 & 28.38 & 2.722 & .962 & & & \\
\hline & \multirow[t]{2}{*}{$\begin{array}{l}\text { Metals and } \\
\text { non-metals }\end{array}$} & $\begin{array}{l}\text { Before } \\
\text { intervention }\end{array}$ & 15 & 28 & 2.268 & .802 & \multirow[t]{2}{*}{4.219} & \multirow[t]{2}{*}{14} & \multirow[t]{2}{*}{.001} \\
\hline & & $\begin{array}{l}\text { After } \\
\text { intervention }\end{array}$ & 15 & 21.63 & 3.623 & 1.281 & & & \\
\hline & \multirow[t]{2}{*}{$\begin{array}{l}\text { Elements and } \\
\text { Compounds }\end{array}$} & $\begin{array}{l}\text { Before } \\
\text { intervention }\end{array}$ & 15 & 19.50 & 1.604 & .567 & \multirow{2}{*}{3.157} & \multirow{2}{*}{14} & \multirow{2}{*}{.007} \\
\hline & & $\begin{array}{l}\text { After } \\
\text { intervention }\end{array}$ & 15 & 12.25 & 3.454 & 1.221 & & & \\
\hline & \multirow[t]{2}{*}{ Total Scores } & $\begin{array}{l}\text { Before } \\
\text { intervention }\end{array}$ & 15 & 78.38 & 4.470 & 1.580 & \multirow[t]{2}{*}{3.730} & \multirow[t]{2}{*}{14} & \multirow[t]{2}{*}{.002} \\
\hline & & $\begin{array}{l}\text { After } \\
\text { intervention }\end{array}$ & 15 & 65.25 & 8.892 & 3.144 & & & \\
\hline
\end{tabular}

Table 5: ANCOVA Scores for Low Achiever Students

\begin{tabular}{|c|c|c|c|c|c|}
\hline Source & Type III Sum of Squares & df & Mean Square & F & Sig. \\
\hline Corrected Model & 1152.846 & 2 & 576.423 & 32.638 & .000 \\
\hline Intercept & 54.354 & 1 & 54.354 & 3.078 & .103 \\
\hline Pre_Total & 463.783 & 1 & 463.783 & 26.260 & .000 \\
\hline Group & 483.482 & 1 & 483.482 & 27.376 & .000 \\
\hline Error & 229.592 & 13 & 17.661 & & \\
\hline Total & 83895.000 & 16 & & & \\
\hline Corrected Total & 1382.438 & 15 & & & \\
\hline
\end{tabular}

R Squared $=.889($ Adjusted R Squared $=.874)$ 
Table 6: Estimated Marginal Means of High Achievers

\begin{tabular}{|l|l|c|c|c|}
\hline \multirow{2}{*}{ Group } & \multirow{2}{*}{ Mean } & \multirow{2}{*}{ Std. Error } & \multicolumn{2}{|l|}{$95 \%$ Confidence Interval } \\
\cline { 4 - 5 } & & & Lower Bound & Upper Bound \\
\hline $\begin{array}{l}\text { Before } \\
\text { Intervention }\end{array}$ & 77.399 & 1.498 & 74.163 & 80.635 \\
\hline After Intervention & 66.226 & 1.498 & 62.990 & 69.462 \\
\hline
\end{tabular}

Covariates: Pre total score test $=27.38$

The ANCOVA analysis of higher achiever students shows that $\mathrm{F}$ ratio at $\mathrm{df} 15$ is $\mathrm{F}_{(1,17)}=27.376$ and $\mathrm{p}=0.000$ is significant at .0001 level. It validates the result of $\mathrm{t}$ - test analysis that reveals that PAR approach significantly enhances the achievement in high achievers. Estimated marginal means of the experimental group (77.399) is higher than control group (66.226) is shown inTable 6.

Chemistry pedagogy at the school system in Nepal is monotonous leading to culture of silence. Question asking practices in the science classroom provides an opportunity to collaborate, deliberate, communicate and co-create the new knowledge among peers. PAR approach provides an opportunity to learn science by the collaboration with teachers in the laboratory, promotes to learn skills. According to Wright (2015), "PAR process can be exercised as a pedagogical strategy to promote representative, collective decision making in which students contribute to an input in the direction of their learning" (p. 25). Understanding and progress in the development of scientific skills among the students is "partially based on arguments"(Acharya, 2017), discourse and cause effect relationship. Williams (2013) states, "formulating arguments is a particular genre of discourse in which a central epistemological framework is formed as a result of scientific actions".

PAR approach of learning in the schools in Nepal, help teachers' intervention, the students have an opportunity to construct individual as well as group knowledge. This sort of co-creation of knowledge can be achieved by applying PAR approach in the classrooms. In this connection Vygotsky (1978) argues, "formulating knowledge in the collaboration of people is an example of constructivist sociocultural knowledge". Active learning process always demands students' engagement in an active way that begins by asking queries, putting problems in front of peers and teachers but it does not simply present the established knowledge or facts by moving in a linear way to get knowledge.

The epistemology of inquiry-based science learning is rooted in an approach to teaching and learning science which reflects an understanding of how students learn chemistry and the concepts as well as content to be learned. Belief of child centered pedagogy is important to ensure that students truly understand what they have learned.

Chemistry teaching learning activities demand inquiry to explore the natural phenomena that can be linked to classroom activities. As a co-researcher, I believe that the main focus of motivating pupils in inquiry-based learning is to get students to understand the real world. Students learn best and participate more in the work when the opportunities are provided to them. As far as the PAR is concerned, science teacher as a co-researcher acts and performs in a real-world i.e. at the community level, which helps to reach the aims to solve real problems.Due to PAR approach, lower achievers take interest in academic task and actively participate in learning activities which contributes towards their success. Therefore lower ability students get benefited lots with the use of PAR activities results in significantly high achievement in post test scores of CAT. The PAR learning classroom creates ample opportunities to the students to work interactively with their peer group and all types of 
students get benefitted from constant coaching, encouragement and constructive feedback from their team members.

\section{Conclusion}

The implementation of PAR in chemistry class has positive effect on diverse ability students of lower and higher achievers. PAR significantly enhances the achievement in chemistry subject. Amalgamation of ABI with the traditional teaching learning process creates opportunities for active learning of the students to understand the concept of chemistry. The classroom atmosphere is shifted from competitive to cooperative environment where, students of diverse ability help and motivate each other to learn. Thus, classroom is full of empathy, cooperation and harmony that reduce occurrence of unpleasant situation and maximizes the achievement of all diverse ability learners.

\section{Acknowledgements}

This paper grew out of the insights gained in course of my $\mathrm{PhD}$ pursuit which was:

i. Registered with the Graduate School of Education, Faculty of Education, Tribhuvan University.

ii. Inspired by the fellowship for $\mathrm{PhD}$ student awarded by NORHED-project, Norway.Therefore, I would like to acknowledge both of the institutions.

\section{References}

1. Acharya, K. P. (2016). Fostering critical thinking practices in primary science classrooms in Nepal. Research in Pedagogy Journal. 6, 2, pp. 1-7. doi: 10.17810/2015.30

2. Acharya, K. P. (2017). Science teachers' information processing behaviours in Nepal: A reflective comparative study. Research in Pedagogy Journal, 7, 1, pp. 1-6. doi: $10.17810 / 2015.43$

3. Feasey, R. (2012). Thinking and working scientifically. In K. Skamp (Ed.) Teaching primary science constructively (4th ed.)(pp. 55-98) Melbourne: Cengage Learning.

4. $\quad$ Freire, P. (1993). Pedagogy of the oppressed (new rev. 20th anniversary ed.).

5. Graesser, A. C., \& Olde, B. (2003). How does one know whether a person understands a device? Journal of Educational Psychology, 95, 524-536.

6. Hofstein, A., Kipnis, M., \& Kind, P. (2008). Learning in and from science laboratories: Enhancing students' metacognition and argumentation skills. In C. L. Petroselli (Ed.), Science education issues and developments (pp. 59-94). New York: Nova Science.

7. Klahr, D. \& Nigam, M. (2004). The equivalence of learning paths in early science instruction: Effects of direct instruction and discovery learning. PsychologicalScience, 15, 661-667. doi:10.1111/j.0956-7976.2004.00737.x

8. Lazonder, A. W. \& Harmsen, R. (2016). Meta-analysis of inquiry-based learning: Effects of guidance. Review of educational research. doi: 10.3102/0034654315627366

9. Lisa, C., Martin, N. \& Adams, O. (2015). Experiential learning through participatory action research in public health supports community-based training of future health professionals. Pedagogy in Health Promotion: The Scholarship of Teaching and Learning 2015, Vol. 1(4) 220-232. doi: 10.1177/2373379915601119

10. McNeill, K. L. (2009). Teachers' use of curriculum to support students in writing scientific arguments to explain phenomena. Science Education, 93, 233-268. doi:10.1002/sce.20294 
11. Shrestha, K. M. (2009). Problems and possibilities of science learning in Nepal. Journal of Science Education. Nepal Science Educational Society, vol. 4, p. 3.

12. Soloway, N., Kishbaugh, C. \& Hayes, J. (1999). Science in the palms of their hands. Communications of the ACM, 42(8), 21-26.

13. Ucar, S. (2011). How do pre-service science teachers' views on science, scientist. And science teaching change over time in a science teacher training program/? Journal of Science Education and Technology, 21 (2), 255-266

14. Vygotsky, L. S. (1978). Mind in society: The development of higher psychological processes. Cambridge: Harvard University Press. 